\title{
RENCANA PRODUKSI OLAHAN KOPI DI PERUSAHAAN DAERAH PERKEBUNAN (PDP) KAHYANGAN JEMBER MENGGUNAKAN METODE FUZZY TSUKAMOTO
}

\author{
Yuli Wibowo ${ }^{1}$, Bambang Herry Purnomo ${ }^{1}$, Yeyen Retno Maulida ${ }^{1 *}$ \\ ${ }^{1}$ Jurusan Teknologi Industri Pertanian, Fakultas Teknologi Pertanian, \\ Universitas Jember \\ Email : yeyenretno287@gmail.com
}

\begin{abstract}
PDP Kahyangan Jember is a regional company owned by the Government of Jember Regency that has agroindustry ground coffee and roasted coffee. The problem is that there was a mismatch between the company's production plan and the number of consumer demand that cause the stock. The impact is that production costs will increase because of the cost of storing and the production process becomes disrupted due to the location of the product storage warehouse in place together with the production space. The purpose of this research is to evaluate and to make a production plan model at PDP Kahyangan Jember. The method used is fuzzy Tsukamoto with input variables in the form of consumer demand and stock. The results showed that the prediction of the quantity of ground coffee and roasted coffee in the past year (July 2017-June 2018) resulted in a MAPE value of $16 \%$. The MAPE value obtained is "good" because it was in between 10-20\%. The results of the fuzzy Tsukamoto model simulation for future production plans are done by predicting the number of requests in advance using the DES Brown method and the stock using the SES method. The forecasting results for the number of requests for coffee were $3,304 \mathrm{~kg}, 3,261 \mathrm{~kg}, 3,219 \mathrm{~kg}, 3,176 \mathrm{~kg}, 3,134 \mathrm{~kg}$, and $3,091 \mathrm{~kg}$. While the stock forecasting results are $283 \mathrm{~kg}, 205 \mathrm{~kg}, 173 \mathrm{~kg}, 151 \mathrm{~kg}, 140 \mathrm{~kg}$, and $134 \mathrm{~kg}$. Therefore, the production plan of coffee processed using fuzzy Tsukamoto for July - December 2018 are $4144 \mathrm{~kg}, 4136 \mathrm{~kg}, 4130 \mathrm{~kg}, 4121 \mathrm{~kg}, 4110 \mathrm{~kg}$ and $4095 \mathrm{~kg}$ respectively.
\end{abstract}

\section{Keyword: fuzzy Tsukamoto, processed coffee, production plan}

\section{PENDAHULUAN}

Saat ini banyak perusahaan yang bergerak di bidang industri pangan maupun non pangan yang dihadapkan pada suatu masalah yaitu adanya tingkat persaingan yang semakin kompetitif. Hal ini mengharuskan perusahaan untuk merencanakan atau menentukan jumlah produksi agar dapat memenuhi permintaan pasar dengan waktu yang tepat dan jumlah yang sesuai. Sehingga keuntungan perusahaan akan meningkat.

PDP Kahyangan Jember merupakan perusahaan daerah yang dimiliki
Pemerintah Kabupaten Jember yang bisnis utamanya bergerak dalam bidang usaha perkebunan. Total luas areal kebun yang dikelola oleh saat ini adalah 3.800,6039 ha (PDP, 2016). Perusahaan ini memiliki agroindustri pengolahan kopi yaitu kopi bubuk dan sangrai dengan nama merk kahyangan.

Permasalahan yang terjadi di PDP Kahyangan Jember adalah terdapat ketidaksesuaian antara rencana produksi perusahaan dengan jumlah permintaan konsumen yang menyebabkan terjadinya kelebihan stok (overstock). Hal ini terbukti pada bulan Maret 2018 jumlah 
kopi bubuk dan sangrai yang diminta oleh konsumen adalah sebanyak $1.259 \mathrm{~kg}$, sedangkan perusahaan memproduksi sebanyak $2.963 \mathrm{~kg}$ dan jumlah produk pada bulan sebelumnya tersisa $28 \mathrm{~kg}$. Hal ini menyebabkan stok kopi bubuk dan sangrai menjadi bertambah. Akibatnya, biaya produksi juga menjadi bertambah karena adanya biaya penyimpanan. Selain itu, stok yang bertambah juga mengakibatkan terganggunya proses produksi karena letak gudang penyimpanan produk jadi menjadi satu dengan ruang produksi.

Untuk dapat mengatasi permasalahan tersebut, maka diperlukan proses rencana produksi menggunakan kecerdasan buatan. Salah satu metode yang dapat digunakan adalah Fuzzy Logic. Fuzzy Logic (logika fuzzy) merupakan ilmu yang mempelajari mengenai ketidakpastian yang memiliki kelebihan yaitu kemampuan dalam proses penalaran secara bahasa (linguistic reasoning). Logika fuzzy memungkinkan nilai keanggotaan antara 0 dan 1 (Ramadhani, 2012). Fuzzy Logic memiliki 3 jenis fuzzy, yaitu: Tsukamoto, Mamdani, dan Sugeno. Pada kasus ini, metode fuzzy yang akan digunakan adalah Tsukamoto. Hal ini dikarenakan fuzzy Tsukamoto memiliki penalaran yang cukup mudah untuk dipahami dan memberikan toleransi terhadap data-data yang tidak tepat (Wiguna, 2015).

Menurut Kusumadewi dan Purnomo (2010), metode fuzzy Tsukamoto merupakan perluasan dari penalaran monoton. Penalaran secara monoton digunakan sebagai dasar untuk teknik implikasi fuzzy. Pada metode ini aturan IF-THEN nya harus diwakili pada suatu himpunan fuzzy, kemudian output hasil perhitungan dari masing-masing aturan diberikan secara tegas berdasarkan perbandingan fungsi keanggotaan dari setiap himpunan fuzzy. Hasil dari perbandingan fungsi keanggotaan tersebut digunakan untuk mencari nilai bobot dari setiap aturan fuzzy, dan hasil akhirnya diperoleh dengan menggunakan rata-rata berbobot.

Tujuan yang ingin dicapai dalam penelitian ini adalah untuk mengevaluasi hasil prediksi jumlah produksi olahan kopi menggunakan fuzzy Tsukamoto, serta membuat model rencana produksi olahan kopi di PDP Kahyangan Jember untuk periode mendatang.

\section{METODE}

\section{Tempat dan Waktu penelitian}

Penelitian ini dilaksanakan di Perusahaan Daerah Perkebunan (PDP) Kahyangan, Jalan Gajah Mada No. 245, Kaliwates, Kabupaten Jember pada bulan Mei sampai Juli 2018.

\section{Tahapan Laksana}

\section{Pemilihan Pakar}

Pada konteks yang terkait permasalahan perencanaan produksi di PDP Kahyangan Jember, peneliti menggunakan 3 pakar. Pakar yang dipilih oleh peneliti berasal dari PDP Kahyangan Jember bagian Unit Usaha Lain (UUL) dan bagian akademisi.

\section{Metode Pengumpulan Data}

Data yang akan dikumpulkan pada penelitian ini adalah data primer dan data sekunder. Data primer diperoleh secara langsung dari objek penelitian melalui proses wawancara dan diskusi dengan pakar menggunakan wawancara, kuesioner dan lainnya. Data sekunder diperoleh dari studi pustaka untuk memperoleh landasan teoris dan data penunjang yang berkaitan dengan topik penelitian. Data sekunder juga bisa diperoleh melalui penelusuran data pada instansi terkait. 


\section{Metode Pengolahan Data}

Tahap pengolahan data pada penelitian ini meliputi teknik sistem yaitu Fuzzy Inference Sytem (FIS) menggunakan metode Tsukamoto menggunakan perangkat lunak atau software sebagai alat bantunya yang dalam penelitian ini menggunakan Microsoft Excel 2010.

\section{Diagram alir Penelitian}

Langkah-langkah diagram penelitian pada Gambar 1 dijelaskan sebagai berikut:

\section{Tahap Identifikasi Sistem}

Tahap identifikasi sistem merupakan tahap awal dari penelitian ini yang terdiri dari studi pendahuluan, identifikasi masalah, dan studi literatur. Studi pustaka merupakan tahap dilakukan untuk mengetahui kondisi dan gambaran saat ini di PDP Kahyangan Jember. Observasi dan wawancara dilaksanakan pada bagian Unit Usaha Lain (UUL) yaitu pada produksi kopi bubuk dan sangrai. Selanjutnya dilaukan identifikasi masalah untuk mengidentifikasi permasalahan yang terjadi pada unit produksi olahan kopi di PDP Kahyangan Jember terkait rencana produksi olahan kopi. Studi pustaka merupakan tahapan untuk menentukan landasan teori dari pokok permasalahan yang akan diteliti serta untuk menentukan metode ilmiah yang digunakan.

\section{Tahap Fuzzifikasi}

Tahap fuzzifikasi meliputi identifikasi variabel fuzzy, pembentukan rulebase (inferensi), dan penentuan komposisi aturan. Berdasarkan hasil kuesioner dan wawancara dengan pakar di UUL PDP Kahyangan Jember, rancangan sistem tersusun dari 2 variabel input dan 1 variabel untuk memprediksi jumlah produksi 1 tahun terakhir (Juli 2017-Juni 2018). Input, output, dan nilai linguistik sebagai himpunan fuzzy yang digunakan sebagai basis pengetahuan dalam pengembangan sistem pakar ini disajikan pada Tabel 1 .

Tabel 1 Nilai label output dan input

\begin{tabular}{lll}
\hline Variabel & Jenis & Nilai \\
& variabel & Linguistik \\
\hline Permintaan & Input & Turun \\
konsumen & & Tetap \\
& & Naik \\
\hline Stok (sisa) & Input & Sedikit \\
& & Sedang \\
& & Banyak \\
\hline Jumlah produksi & Output & Berkurang \\
& & Sedang \\
& & Bertambah \\
\hline
\end{tabular}

Nilai keanggotaan himpunan jumlah produksi, permintaan dan stok barang saat ini dicari menggunakan fungsi keanggotaan himpunan fuzzy berdasarkan hasil wawancara dan data sekunder yang berasal dari PDP Kahyangan Jember dengan memperhatikan nilai maksimum dan nilai minimum data 3 periode terakhir (Juli 2015-Juni 2018) dari tiap variabel. Pendekatan yang digunakan pada penelitian ini adalah bentuk bahu dan segitiga.

Inferensi adalah proses penggabungan banyak aturan (rule) berdasarkan 2 variabel input dan satu variabel output yang telah didefinisikan dengan susunan aturan IF AND - THAN. Rule didapatkan dari wawancara dan pembagian kuesioner kepada para pakar. Salah satu contoh aturan (rulebase) dapat dilihat pada Tabel 2 .

Tabel 2Rulebase

\begin{tabular}{lll}
\hline \multicolumn{1}{c}{ Aturan 1 } & \multicolumn{1}{c}{ Parameter } & \multicolumn{1}{c}{ Nilai } \\
\hline IF & Permintaan & Turun \\
AND & Stok (sisa) & Sedikit \\
THEN & Produksi & Berkurang \\
\hline
\end{tabular}

Tahap penentuan komposisi aturan dilakukan untuk, menentukan fire-strenght ( $\alpha$-predikat) dengan mengambil nilai minimum (MIN) dari seluruh nilai derajat keanggotaan. Pada metode fuzzy Tsukamoto, operasi himpunan yang 
digunakan untuk menghitung jumlah produksi olahan kopi adalah konjungsi (AND). Hasil operasi dengan operator AND dari masing-masing aturan diperoleh dengan:

$$
\mu_{\mathrm{A} \cap \mathrm{B}}=\min \left(\mu_{\mathrm{A}}\left[\mathrm{x}_{1}\right], \mu_{\mathrm{B}}\left[\mathrm{x}_{2}\right]\right)
$$

Dimana:

A,B : variabel yang digunakan

$\mathrm{x}_{1}, \mathrm{x}_{2}$ : Himpunan fuzzy yang digunakan pada setiap variabel

\section{Tahap Defuzzifikasi}

Defuzzifikasi dilakukan untuk mendapatkan nilai output (crisp) adalah dengan mengubah input menjadi suatu bilangan pada domain himpunan fuzzy. Pada metode Tsukamoto, untuk menentukan nilai output (crisp) digunakan "Metode rata-rata terpusat" atau "Metode defuzzifikasi rata-rata terpusat (Center Average Deffuzzyfier). Secara umum dapat dituliskan pada rumus persamaan seperti berikut:

$$
Z=\frac{\sum_{i=1}^{n} \alpha_{i} z_{i}}{\sum_{i=1}^{n} \alpha_{i}}
$$

Dimana :

$\mathrm{Z}=$ nilai output (crisp)

$\alpha \mathrm{i}=$ nilai $\alpha$-predikat pada aturan ke-i

$\mathrm{zi}=$ nilai variabel output masing-masing dari aturan ke-i

\section{Tahap Pengujian}

Tahap pengujian dilakukan menggunakan metode MAPE (Mean Absolute Percentage Error). Menurut Pakaja (2012), MAPE merupakan pengukuran kesalahan yang dihitung dengan menggunakan kesalahan absolut pada tiap periode dibagi dengan nilai observasi yang nyata pada periode tersebut. MAPE dapat dihitung dengan rumus sebagai berikut:

$$
\mathrm{MAPE}=\left(\frac{100 \%}{n}\right) \sum_{t=1}^{n}\left|\frac{X t-F t}{X t}\right|
$$

Dimana :

$\mathrm{Xt}$ : Data aktual pada periode $\mathrm{t}$

$\mathrm{Ft}$ : Nilai peramalan pada periode $\mathrm{t}$

$\mathrm{n}$ : Jumlah data

\section{Tahap Simulasi Model}

Pada tahap simulasi ini dilakukan prediksi terhadap rencana produksi kedepan sampai bulan Desember 2018 menggunakan model Fuzzy Inference System (FIS) yaitu metode Tsukamoto. Data yang digunakan untuk mengetahui rencana produksi tersebut adalah data hasil peramalan permintaan dan stok. Pada penelitian ini, jumlah permintaan diramal menggunakan metode Double Exponential Smoothing (DES) Brown, sementara itu jumlah stok diramal menggunakan metode Single Exponential Smoothing (SES).

Menurut Makridakis (2003), pemulusan Eksponensial Ganda (DES) dari Brown merupakan model linear yang dikemukakan oleh Brown. Metode ini digunakan ketika data menunjukkan adanya trend. Rumus untuk DES Brown adalah sebagai berikut:

$$
\begin{aligned}
& S_{t}^{\prime}=\alpha X_{t}+(1-\alpha) S_{t-1}^{\prime} \\
& S_{t}^{\prime \prime}=\alpha S_{t}^{\prime}+(1-\alpha) S^{\prime \prime}{ }_{t-1} \\
& a_{t}=2 S_{t}^{\prime}-S^{\prime \prime} t-1 \\
& b_{t}=\frac{\alpha}{(1-\alpha)}\left(S_{t}^{\prime}-S^{\prime \prime} t-1\right) \\
& F_{t+m}=a_{t}+b_{t} m
\end{aligned}
$$

Dimana:

$S ' t=$ Nilai pemulusan exponential tunggal

S"t = Nilai pemulusan exponential ganda

$a_{t}, b_{t}=$ Konstanta pemulusan

$\alpha=$ Parameter pertama perataan (0-1)

$\mathrm{F}_{\mathrm{t}+\mathrm{m}}=$ Hasil peramalan ke- $\mathrm{m}$ 
$\mathrm{m}=$ Jumlah periode ke depan yang akan diramalkan

Single Exponential Smoothing (SES) adalah suatu prosedur yang secara terus menerus memperbaiki prediksi dengan merata-rata nilai masa lalu dari suatu data deret waktu dengan cara menurun (Gustriansyah, 2017). Metode SES lebih cocok digunakan untuk memprediksi halhal yang fluktuasinya secara acak (tidak teratur) yang tidak dipengaruhi trend atau musiman. Rumus untuk SES adalah sebagai berikut :

$$
F_{t+1}=a X_{t}+(1-\alpha) F_{t}
$$

\section{Dimana:}

$\mathrm{Ft}=$ Peramalan untuk perode $\mathrm{t}$

$X_{t}+1(1-\alpha)=$ Nilai aktual time series

$\mathrm{F}_{\mathrm{t}+1} \quad=$ Peramalan pada waktu $\mathrm{t}+1$

A $=$ Konstanta pemulusan antara 0 dan 1

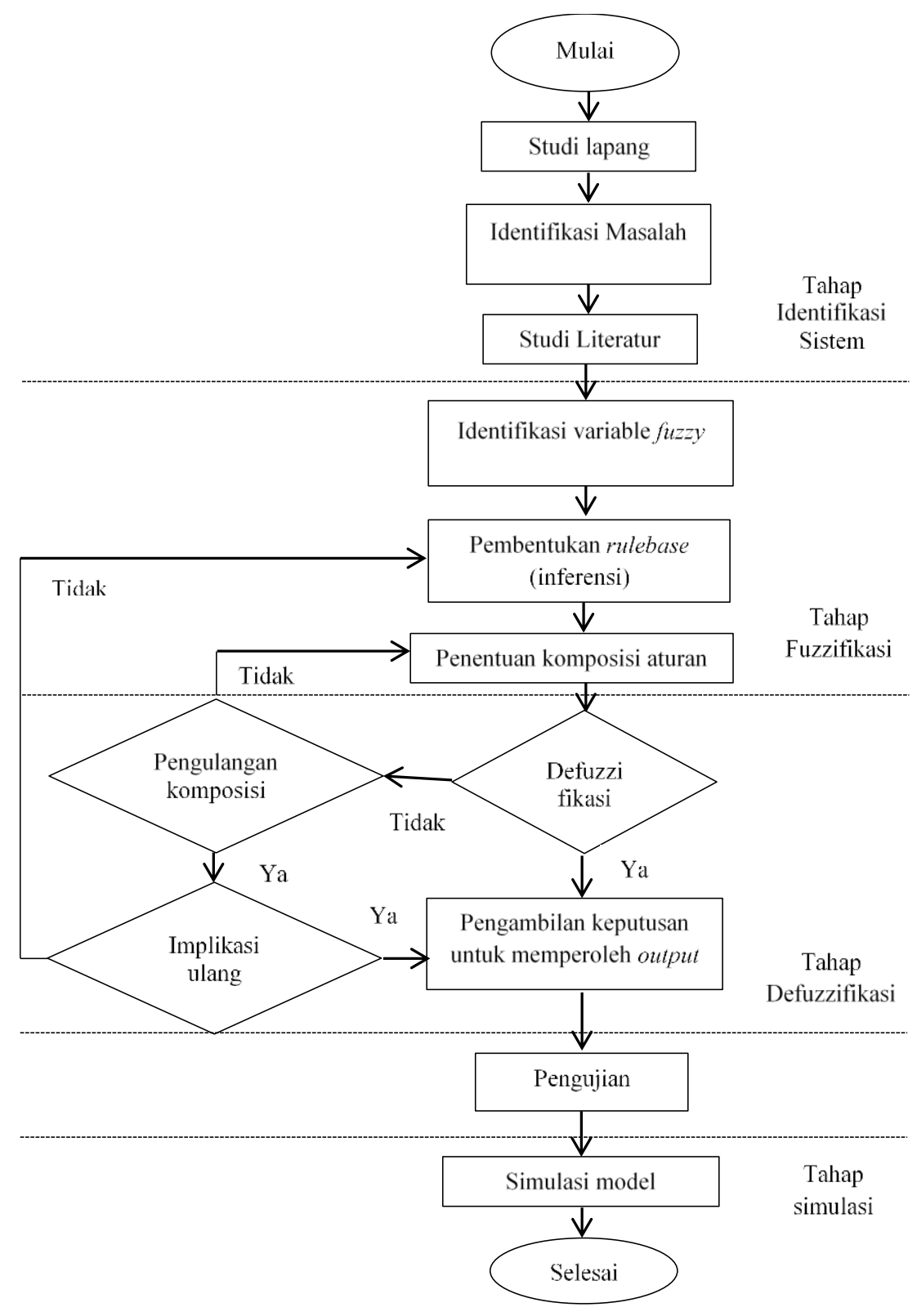

Gambar 1Diagram Alir Penelitian 


\section{HASIL DAN PEMBAHASAN}

Proses Fuzzifikasi

Berdasarkan hasil identifikasi variabel, dari data 3 tahun terakhir (Juli 2015 - Juni 2018) diperoleh data maksimum dan minimum dari masingmasing variabel input dan output seperti padaTabel 3 .

Tabel 3Data Makimum dan data minimum

\begin{tabular}{lccc}
\hline \multicolumn{1}{c}{ Data } & Jumlah & Satuan \\
\hline Permintaan maksimum & 1.259 & $\mathrm{Kg} / \mathrm{bulan}$ \\
Permintaan minimum & 5.640 & $\mathrm{Kg} / \mathrm{bulan}$ \\
Stok maksimum & 29 & $\mathrm{Kg} / \mathrm{bulan}$ \\
Stok minimum & 4.939 & $\mathrm{Kg} / \mathrm{bulan}$ \\
Produksi minimum & 1.531 & $\mathrm{Kg} / \mathrm{bulan}$ \\
Produksi maksimum & 6798 & $\mathrm{Kg} / \mathrm{bulan}$ \\
\hline
\end{tabular}

Fungsi keanggotaan dari masingmasing variabel input maupun output adalah sebagai berikut:

a. Representasivariabelpermintaan Variabel permintaan terbagi menjadi 3 himpunan fuzzy, yaitu Turun [0 3.449], Tetap [1.259 5.640], dan Naik [3.449 $\infty]$. Himpunan Turun dan Naik menggunakan pendekatan fungsi keanggotaan berbentuk bahu, -sedangkan himpunan Tetap menggunakan pendekatan berbentuk segitiga.

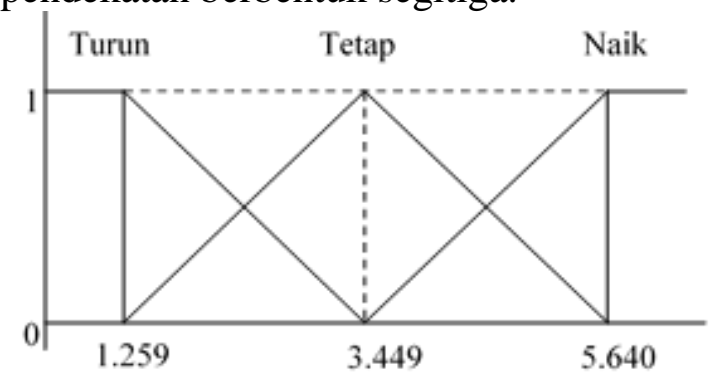

Gambar 2 Fungsi Keanggotaan Variabel Permintaan

Fungsi keanggotaan pada variabel permintaan dirumuskan sebagai berikut,

$$
\operatorname{PmtNaik}(x)=\left\{\begin{array}{cc}
1 & x \leq 1.259 \\
\frac{3.449-x}{3.449-1.259} & 1.259 \leq x \leq 3.449 \\
0 & x \geq 3.449
\end{array}\right.
$$

$$
\begin{gathered}
\text { PmtTetap }(x)=\left\{\begin{array}{cc}
1 & x=3.449 \\
\frac{x-1.259}{3.449-1.259} & 1.259 \leq x \leq 3.449 \\
\frac{5.640-x}{5.640-3.449} & 3.449 \leq x \leq 5.640 \\
0 & x \leq 1.259 \text { atau } x \geq 5.640
\end{array}\right. \\
\text { PmtTurur } x)=\left\{\begin{array}{cc}
0 & x \leq 3.449 \\
\frac{x-3.449}{5.640-3.449} & 3.449 \leq x \leq 5.640 \\
1 & x \geq 5.640
\end{array}\right.
\end{gathered}
$$

b. Representasi variabel stok

Variabel stok terbagi menjadi 3 himpunan fuzzy, yaitu Sedikit [0 2.483], Sedang [28 4.939], Banyak [2.483 œ]. Himpunan Sedikit dan Banyak menggunakan pendekatan fungsi keanggotaan berbentuk bahu, sedangkan himpunan Sedang menggunakan pendekatan berbentuk segitiga.

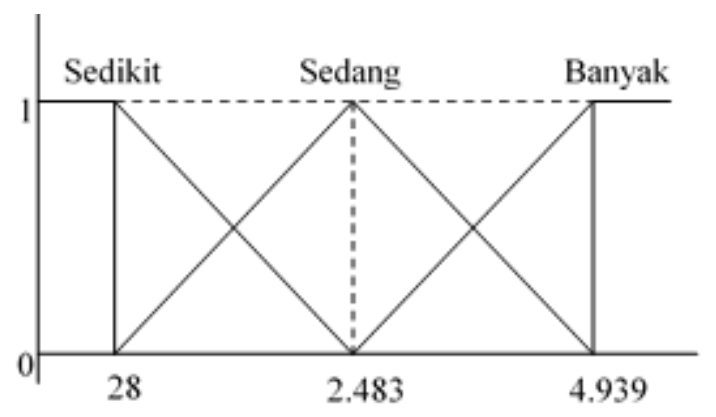

Gambar 3Fungsi Keanggotaan Variabel Stok

Fungsi keanggotaan pada variabel stok dirumuskan sebagai berikut,

$$
\begin{aligned}
& \text { StokSedikti }(y)=\left\{\begin{array}{cc}
1 & y \leq 28 \\
\frac{2.483-y}{2.483-28} & 28 \leq y \leq 2.483 \\
0 & y \geq 2.483
\end{array}\right. \\
& \text { StokSedangy })=\left\{\begin{array}{cc}
1 & y=2.483 \\
\frac{y-28}{2.483-28} & 28 \leq y \leq 2.483 \\
\frac{4.939-y}{4.939-2.483} & 2.483 \leq y \leq 4.939 \\
0 & y \leq 28 \text { atau } y \geq 4.939
\end{array}\right.
\end{aligned}
$$$$
\text { StokBanyak }(y)=\left\{\begin{array}{cc}
0 & y \leq 2.483 \\
\frac{y-2.483}{4.939-2.483} & 2.483 \leq y \leq 4.939 \\
1 & y \geq 4.939
\end{array}\right.
$$

c. Representasi variabel produksi

Variabel produksi terbagi menjadi 3 himpunan fuzzy, yaitu Berkurang [0 4.165], Sedang [1.531 6.798], dan Naik 
[4.165 $\infty]$. Himpunan Berkurang dan Bertambah menggunakan pendekatan fungsi keanggotaan berbentuk bahu, sedangkan himpunan Sedang menggunakan pendekatan berbentuk segitiga.

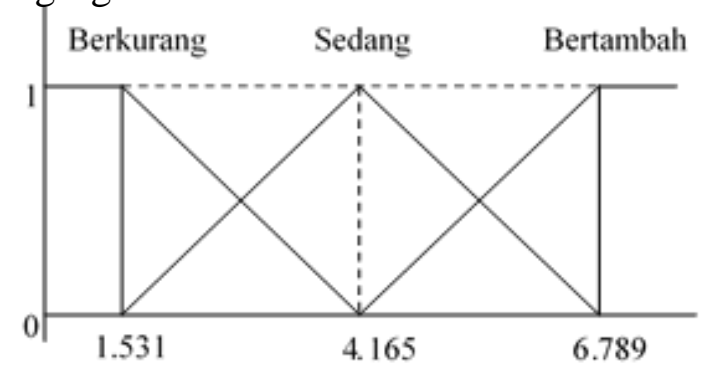

Gambar 4Fungsi Keanggotaan Variabel Produksi

Fungsi keanggotaan pada variabel permintaan dirumuskan sebagai berikut,

$$
\begin{gathered}
\text { PdsBerkurang }(z)=\left\{\begin{array}{cc}
1 & z \leq 1.531 \\
\frac{4.165-z}{4.165-1.531} & 1.531 \leq z \leq 4.165 \\
0 & z \geq 4.165
\end{array}\right. \\
\text { PdsSedang }(z)=\left\{\begin{array}{cc}
1 & x=4.785 \\
\frac{z-1.531}{4.165-1.531} & 1.531 \leq z \leq 4.165 \\
\frac{6.798-z}{6.798-4.165} & 4.165 \leq z \leq 6.798 \\
0 & z \leq 1.531 \text { atau } z \geq 6.798
\end{array}\right.
\end{gathered}
$$$$
\operatorname{PdsBertambah}(z)=\left\{\begin{array}{cc}
0 & z \leq 4.165 \\
\frac{z-4.165}{6.798-4.165} & 4.165 \leq z \leq 6.798 \\
1 & z \geq 6.798
\end{array}\right.
$$

\section{Rulebase Fuzzy (Inferensi)}

Terdapat 7 aturan fuzzy yang digunakan yaitu dapat dilihat pada Tabel 4.

\section{Defuzzifikasi}

Hasil perhitungan defuzzifikasi akan diketahui nilai z yang merupakan jumlah produksi dari hasil peramalan menggunakan FIS Tsukamoto pada bulan Juni 2017-Juli 2018. Grafik perbandingan hasil perhitungan metode fuzzy Tsukamoto dengan data aktual PDP kahyangan jember selama 1 tahun terakhir dapat dilihat pada Gambar 5.

Dari grafik dapat diketahui pada bulan Juli 2017, September 2017 dan Maret 2018 jumlah produksi hasil FIS Tsukamoto lebih rendah dari pada data jumlah produksi PDP Kahyangan Jember. Akan tetapi, pada bulan-bulan lainnya jumlah produksi hasil FIS Tsukamoto lebih tinggi dari pada jumlah produksi pabrik. Menurut Priyo (2017), dalam merencanakan produksi harus memperhatikan faktor keseimbangan antara permintaan, stok dan produksi. Sehingga dapat memberikan dampak positif pada bulan-bulan selanjutnya.

Tabel 4 Rulebase Fuzzy

\begin{tabular}{|c|l|}
\hline$[R 1]$ & IF Permintaan TURUN And Stok barang SEDIKIT THEN Produksi Kopi BERKURA NG; \\
\hline$[R 2]$ & IF Permintaan TURUN And Stok barang SEDANG THEN Produksi Kopi BERKURANG; \\
\hline$[R 3]$ & IF Permintaan TETAP And Stok barang SEDIKIT THEN Produksi Kopi SEDANG; \\
\hline$[R 4]$ & IF Permintaan TETAP And Stok barang SEDANG THEN Produksi Kopi SEDANG; \\
\hline$[$ R5] & IF Permintaan NAIK And Stok barang SEDIKIT THEN Produksi Kopi BERTAMBAH; \\
\hline$[R 6]$ & IF Permintaan NAIK And Stok barang SEDANG THEN Produksi Kopi BERTAMBAH; \\
\hline$[R 7]$ & IF Permintaan NAIK And Stok barang BANYAK THEN Produksi Kopi SEDANG. \\
\hline
\end{tabular}




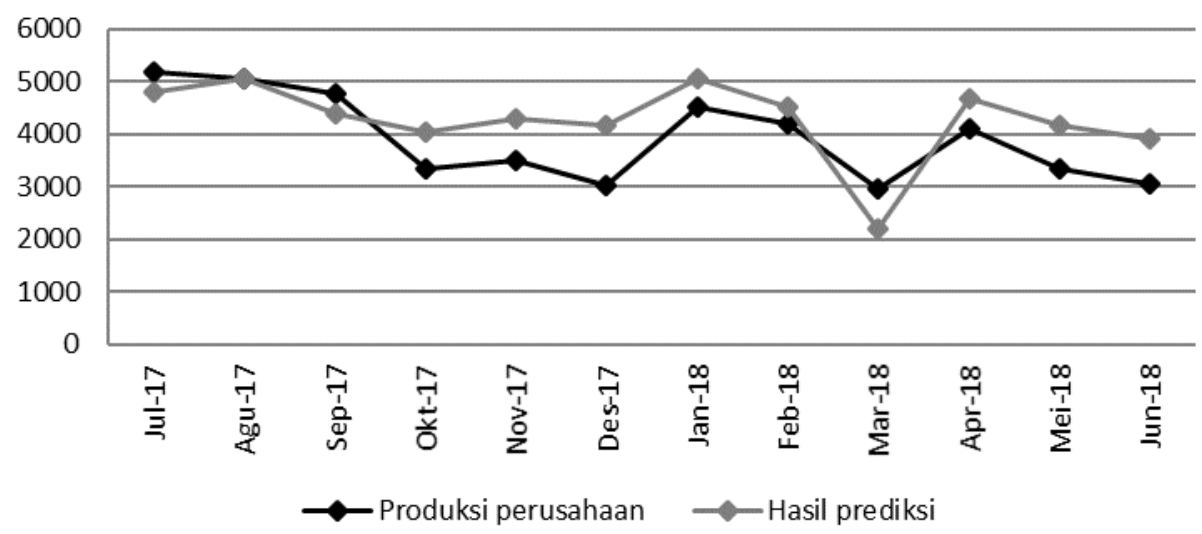

Gambar 5Grafik Perbandingan Produksi Perusahaan dan Hasil Prediksi

Analisa Hasil Pengujian Menggunakan MAPE

Setelah didapatkan hasil prediksi atau peramalan jumlah produksi olahan kopi dalam periode Juli 2017 sampai Juni 2018 menggunakan FIS Tsukamoto, maka selanjutnya diuji tingkat akurasinya menggunakan metode MAPE (Mean Absolute Percentage Error). Nilai MAPE atau hasil pengujian produksi olahan kopi kahyangan setiap bulan dalam satu tahun terakhir (Juli 2017 - Juni 2018) dapat dilihat pada Tabel 5.

Tabel 5Hasil pengujian produksi olahan kopi

\begin{tabular}{lccc}
\hline \multicolumn{1}{c}{ Bulan } & $\begin{array}{c}\text { Produksi } \\
\text { perusahaan } \\
(\mathrm{kg})\end{array}$ & $\begin{array}{c}\text { Hasil } \\
\text { prediksi } \\
(\mathrm{kg})\end{array}$ & $\begin{array}{c}\text { MAPE } \\
(\%)\end{array}$ \\
\hline Juli 2017 & 5.192 & 4.799 & 7,56 \\
Agustus 2017 & 5.065 & 5.045 & 0,39 \\
September 2017 & 4.790 & 4.386 & 8,44 \\
Oktober 2017 & 3.350 & 3.908 & 16,65 \\
November 2017 & 3.494 & 4.300 & 23,09 \\
Desember 2017 & 3.025 & 4.172 & 37,89 \\
Januari 2018 & 4.533 & 5.064 & 11,73 \\
Februari 2018 & 4.209 & 4.512 & 7,20 \\
Maret 2018 & 2.963 & 2.155 & 27,25 \\
April 2018 & 4.094 & 4.680 & 14,31 \\
Mei 2018 & 3.348 & 4.155 & 24,13 \\
Juni 2018 & 3.064 & 3.872 & 26,37 \\
\hline \multicolumn{4}{c}{ Rata-rata } \\
\hline
\end{tabular}

Berdasarkan tabel diatas dapat diketahui rata-rata nilai MAPE-nya adalah sebesar $16 \%$. Nilai MAPE yang diperoleh termasuk dalam kategori baik. Hal ini sesuai dengan literatur yang menyebutkan bahwa suatu model dikatakan mempunyai kinerja "baik" jika nilai MAPE berada diantara 10-20\% (Pakaja, 2012). Sehingga, metode FIS Tsukamoto dapat dijadikan sebagai rekomendasi untuk perusahaan dalam merencanakan jumlah produksi olahan kopi di bulan-bulan selanjutnya.

\section{Hasil Simulasi Model}

a. Hasil peramalan variabel permintaan

Data yang digunakan untuk meramalkan jumlah permintaan adalah data permintaan 3 tahun terakhir (20152018) menggunakan metode DES Brown dengan bantuan Microsoft Excel 2010. Grafik data hasil peramalan dapat dilihat pada Gambar 6.

Dari Grafik diatas dapat diketahui bahwa antara data aktual dan hasil peramalan menunjukkan adanya perbedaan. Perbedaan paling jauh khususnya terjadi pada bulan Maret 2016 dengan data aktual sebesar $1.789 \mathrm{~kg}$ sedangkan hasil ramalannya adalah 4.896 $\mathrm{kg}$ dan pada bulan Maret 2018 dengan data aktual $1.259 \mathrm{~kg}$ sedangkan hasil peramalannya adalah sebesar $3.988 \mathrm{~kg}$. Perbedaan yang cukup jauh ini membuat nilai error semakin besar. Nilai MAD dan MSE yang diperoleh dari hasil peramalan pada bulan Juli 2015 sampai bulan Juni 2018 adalah sebesar 733,417 dan 978.025. Menurut Pujiati (2016), semakin kecil nilai kesahan (error) maka nilai taksiran semakin mendekati nilai sebenarnya, atau 
metode yang dipilih merupakan metode terbaik. Nilai konstanta $(\alpha)$ yang digunakan pada metode ini adalah 0,1 . Nilai ini didapat dari hasil trial and error. Sehingga didapatkan hasil peramalan mendatang untuk jumlah permintaan kopi pada bulan Juli - Desember 2018 berturut- turut adalah $3.304 \mathrm{~kg}, 3.261 \mathrm{~kg}, 3.219 \mathrm{~kg}$, $3.176 \mathrm{~kg}, 3.134 \mathrm{~kg}$ dan $3.091 \mathrm{~kg}$. Hasil peramalan permintaan yang didapat menurun dikarenakan trend yang terbentuk pada grafik diatas juga cenderung menurun diakhir periode.

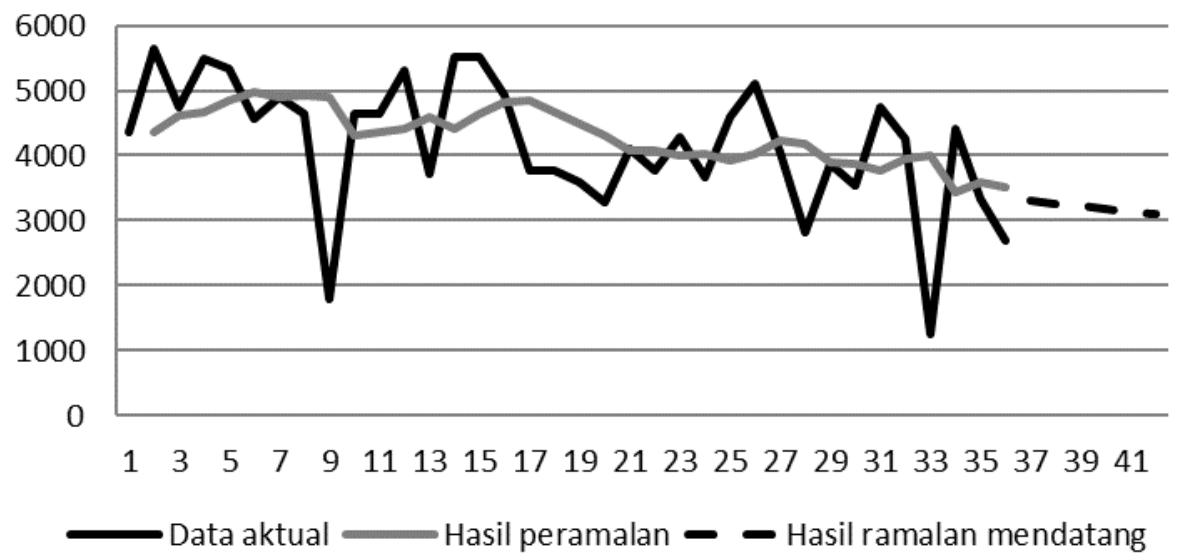

Gambar 6Grafik Hasil Peramalan Permintaan

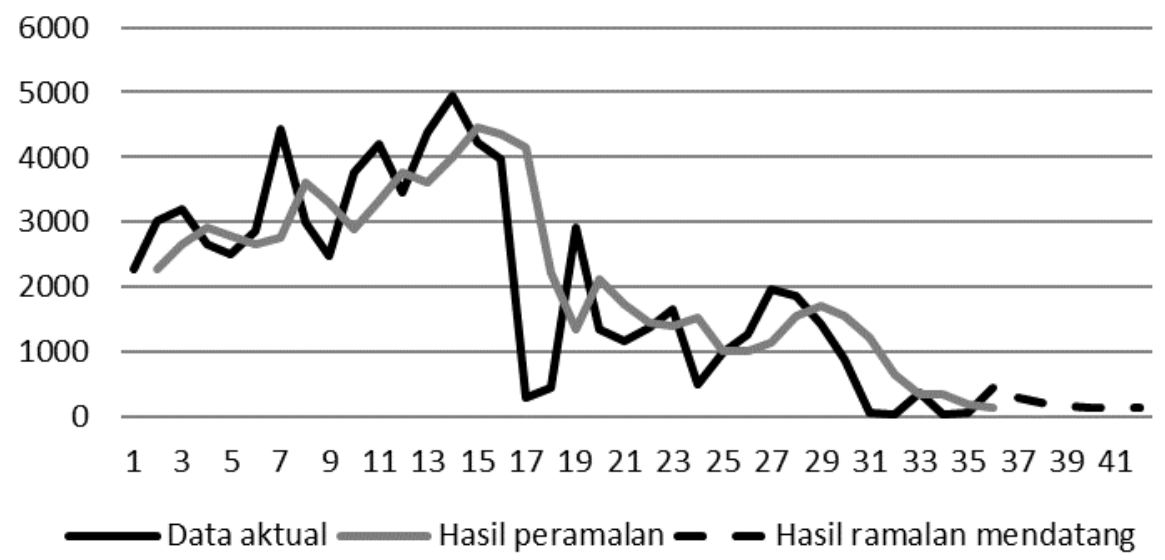

Gambar 7Grafik Hasil Peramalan stok

b. Hasil peramalan variabel stok

Data yang digunakan untuk meramalkan jumlah stok adalah data stok kopi 3 tahun terakhir (2015-2018) menggunakan metode SES dengan bantuan Microsoft Excel 2010. Grafik data hasil peramalan dapat dilihat pada Gambar 7.

Dari grafik diatas dapat diketahui bahwa antara data aktual dan hasil peramalan menunjukkan adanya perbedaan. Perbedaan stok paling jauh khususnya terjadi pada bulan Januari 2016 dengan data aktual sebesar $4.446 \mathrm{~kg}$ sedangkan hasil peramalannya adalah sebesar $2.758 \mathrm{~kg}$, bulan November 2016 dengan data aktual sebesar $288 \mathrm{~kg}$ sedangkan hasil peramalannya adalah sebesar $4.156 \mathrm{~kg}$, bulan Desember 2016 dengan data aktual sebesar $453 \mathrm{~kg}$ sedangkan hasil peramalannya adalah sebesar $2.222 \mathrm{~kg}$, bulan Juni 2017 dengan data aktual sebesar $513 \mathrm{~kg}$ sedangkan hasil peramalannya adalah sebesar 1.536 
$\mathrm{kg}$, dan pada bulan Januari 2018 dengan data aktual sebesar $64 \mathrm{~kg}$ sedangkan hasil peramalannya adalah sebesar $1.225 \mathrm{~kg}$.

Nilai MAD dan MSE yang diperoleh dari hasil peramalan pada bulan Juli 2015 sampai bulan Juni 2018 adalah sebesar 699 dan 979.378. Menurut Pujiati (2016), semakin kecil nilai kesahan (error) maka nilai taksiran semakin mendekati nilai sebenarnya, atau metode yang dipilih merupakan metode terbaik. Nilai konstanta ( $\square$ ) yang digunakan pada metode ini adalah 0,5 . Nilai ini didapat dari hasil trial and error.

Dilihat dari grafik data aktual diatas, variabel stok memiliki pola data yang acak dan tidak teratur. Menurut Gustriansyah (2017), metode SES memang lebih cocok digunakan untuk memprediksi hal-hal yang fluktuasinya secara acak (tidak teratur) yang tidak dipengaruhi trend maupun musiman seperti data stok diatas. Sehingga didapatkan hasil peramalan mendatang untuk jumlah stok produk olahan kopi pada bulan Juli - Desember2018 berturutturut adalah $283 \mathrm{~kg}, 205 \mathrm{~kg}, 173 \mathrm{~kg}, 151$ $\mathrm{kg}, 140 \mathrm{~kg}$ dan $134 \mathrm{~kg}$.

c. Hasil rencana produksi
Dalam hal ini, rencana produksi dimasa yang akan datang dihitung menggunakan metode fuzzy Tsukamoto dengan menggunakan 2 variabel input yaitu permintaan dan stok yang nilainya telah di prediksi sebelumnya. Grafik hasil rencana produksi olahan kopi untuk 6 bulan mendatang (Juni-Juli 2018) dapat dilihat pada Gambar 8 .

Hasil rencana produksi olahan kopi (kopi bubuk dan kopi sangrai) untuk bulan Juli 2018 adalah sebanyak $4.144 \mathrm{~kg}$, bulan Agustus 2018 sebanyak $4.136 \mathrm{~kg}$, bulan September 2018 sebanyak $4.130 \mathrm{~kg}$, bulan Oktober 2018 sebanyak $4.121 \mathrm{~kg}$, bulan November 2018 sebanyak $4.110 \mathrm{~kg}$ dan bulan Desember 2018 adalah sebanyak $4.095 \mathrm{~kg}$. Hasil rencana produksi yang diperoleh dari metode fuzzy Tsukamoto ini cenderung menurun karena hasil peramalan variabel permintaan dan stok yang digunakan sebagai input juga menurun. Namun, jika dilihat dari data aktual pada bulan Juni 2018 yaitu sebanyak $3.064 \mathrm{~kg}$, menandakan bahwa hasil peramalan menggunakan fuzzy Tsukamoto untuk produksi olahan kopi akan mengalami peningkatan pada bulan Juli 2018. Sedangkan untuk bulan-bulan selanjutnya akan menurun.

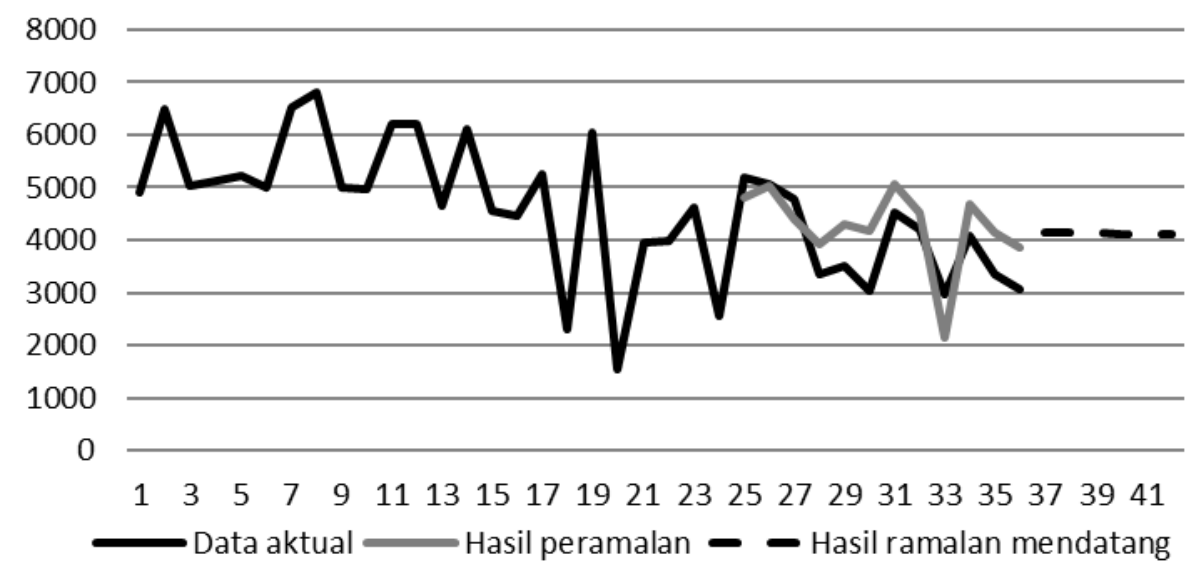

Gambar 8Grafik Hasil Rencana Produksi Mendatang 


\section{KESIMPULAN}

Hasil prediksi jumlah produksi kopi bubuk dan sangrai menggunakan metode fuzzy Tsukamoto berdasarkan data permintaan dan stok di PDP Kahyangan Jember satu tahun terakhir (Juli 2017 Juni 2018) menghasilkan nilai MAPE sebesar $16 \%$. Nilai MAPE yang diperoleh dikatakan "baik" karena berada diantara $10-20 \%$. Sehingga, metode ini dapat dijadikan sebagai rekomendasi untuk perusahaan dalam merencanakan jumlah produksi olahan kopi untuk periode mendatang.

\section{REFERENCES}

Gustriansyah, Rendra. 2017. Analisis Metode Single Exponential Smoothing Dengan Brown Exponential Smoothing pada Studi Kasus Memprediksi Kuantiti Penjualan Produk Farmasi di Apotek. Seminar Nasional Teknologi Informasi dan Multimedia. Yogyakarta: STMIK AMICOM.

Kusumadewi, S., dan Purnomo, H. 2010. Aplikasi Logika Fuzzy untuk Pendukung Keputusan. Yogyakarta: Graha Ilmu.

Makridakis, S., Steven C Wheelwright., Victor E Mc.Gee. 2003. Metode dan Aplikasi Peramalan. Jilid 1. Edisi Revisi. Jakarta: Binarupa Aksara.

Pakaja, F., Naba, A., Purwanto. 2012. Peramalan Penjualan Mobil
Menggunakan Jaringan Syaraf Tiruan dan Certainty Factor. Jurnal EECCIS. 6(1): 23-28.

PDP. 2016. Business Plan Tahun 20162020. Jember: Perusahaan Daerah Perkebunan.

Priyo, W. T. 2017. Penerapan Logika Fuzzy dalam Optimasi Produksi Barang Menggunakan Metode Mamdani. Jurnal Ilmiah. 5(1): 1421.

Pujiati, E., D. Yuniarti, dan R. Goejantoro. 2015. Peramalan dengan Menggunakan metode Double Exponential Smoothing dari Brown (Studi Kasus: Indeks Harga Konsumen (IHK) Kota Samarinda). Jurnal EKSPONENSIAL. 7(1): 3340.

Ramadhani, I., I. S. Rifkan, N. Endarsari, \& S. N. Huda. 2012. Fuzzy Inference System dengan Metode Sugeno untuk Penentuan Banyaknya Asisten Laboratorium yang Diterima pada Saat Rekrutmen. SNATI. Yogyakarta: Universitas Islam Indonesia.

Wiguna, R. Y., dan H. Haryanto. 2015. Sistem Berbasis Aturan Menggunakan Logika Fuzzy Tsukamoto untuk Prediksi Jumlah Produksi Roti pada CV. Gendis Bakery. 